\title{
Universiteit
}

Leiden

The Netherlands

\section{Reading aloud in Persian: ERP evidence for an early locus of the masked onset priming effect.}

Timmer, K.; Vahid-Gharavi, N.; Schiller, N.O.

\section{Citation}

Timmer, K., Vahid-Gharavi, N., \& Schiller, N. O. (2012). Reading aloud in Persian: ERP evidence for an early locus of the masked onset priming effect. Brain And Language, 122, 34-41. Retrieved from https://hdl.handle.net/1887/19557

Version: $\quad$ Not Applicable (or Unknown)

License: $\quad$ Leiden University Non-exclusive license

Downloaded from: https://hdl.handle.net/1887/19557

Note: To cite this publication please use the final published version (if applicable). 
Regular Article

\title{
Reading aloud in Persian: ERP evidence for an early locus of the masked onset priming effect
}

\author{
Kalinka Timmer ${ }^{\text {a,b,*}}$, Narges Vahid-Gharavi ${ }^{\text {a }}$, Niels O. Schiller ${ }^{\text {a,b }}$ \\ a Leiden University Centre for Linguistics (LUCL), The Netherlands \\ ${ }^{\mathrm{b}}$ Leiden Institute for Brain and Cognition (LIBC), The Netherlands
}

\section{A R T I C L E I N F O}

\section{Article history:}

Accepted 23 April 2012

Available online 24 May 2012

\section{Keywords:}

Reading aloud

Masked onset priming effect

Dual-route cascaded model

Speech planning

Grapheme-to-phoneme conversion

Persian

\begin{abstract}
A B S T R A C T
The current study investigates reading aloud words in Persian, a language that does not mark all its vowels in the script. Behaviorally, a masked onset priming effect (MOPE) was revealed for transparent words, with faster speech onset latencies in the phoneme-matching condition (i.e. phonological prime and target onset overlap; e.g. سمال/Sb:l/; 'year' - صوت صوت/Sot/; 'voice') than the phoneme-mismatching condition (e.g.

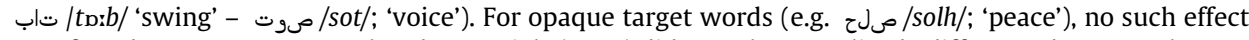
was found. However, event-related potentials (ERPs) did reveal an amplitude difference between the two prime conditions in the $80-160$ ms time window for transparent as well as opaque words. Only for the former, this effect continued into the $300-480 \mathrm{~ms}$ time window. This finding constrains the time course of the MOPE and suggests the simultaneous activation of both the non-lexical grapheme-to-phoneme and the lexical route in the dual-route cascaded (DRC) model.
\end{abstract}

(c) 2012 Elsevier Inc. All rights reserved.

\section{Introduction}

In western alphabetical languages, an effect that gives an insight into the process of reading aloud is the so-called masked onset priming effect (MOPE). The MOPE was first described by Forster and Davis (1991) and reflects faster speech onset latencies for target words that are preceded by a prime sharing its onset with the target (e.g. custom - CARPET), compared to an unrelated prime (e.g. powder - CARPET). This effect has been replicated in English (Kinoshita, 2000, 2003; Kinoshita \& Woollams, 2002; Malouf \& Kinoshita, 2007), Dutch (Schiller, 2004, 2007, 2008), French (Carreiras, Ferrand, Grainger, \& Perea, 2005; Grainger \& Ferrand, 1996), and Spanish (Carreiras, Perea, Vergara, \& Pollatsek, 2009; Dimitropoulou, Duñabeitia, \& Carreiras, 2010). There is evidence that the MOPE is due to phonological (e.g. kernel [kernəl] - CARPET [karpət]) rather than graphemic onset-overlap (e.g. circus [sırkəs] CARPET [karpət]; e.g. Mousikou, Coltheart, \& Saunders, 2010; Rastle \& Brysbaert, 2006; Schiller, 2007; Timmer \& Schiller, submitted).

According to the dual-route cascaded (DRC) model, the MOPE reflects the serial process of converting graphemes into phonemes (GPC) with its locus in the non-lexical route rather than the lexical route (Coltheart, Rastle, Perry, Langdon, \& Ziegler, 2001; Mousikou et al., 2010). The two routes are the fundamental property of this

* Corresponding author. Address: Cognitive Psychology Unit, Department of Psychology, Faculty of Social Sciences, Leiden University, 2300 RB Leiden, The Netherlands.

E-mail address: ktimmer@fsw.leidenuniv.nl (K. Timmer). model. The lexical route entails retrieving the phonology of a word as a whole from the mental lexicon. Thus, the retrieval of all phonological segments occurs in parallel as is assumed by previous models like the parallel distributed processing (PDP) model (Seidenberg \& McClelland, 1989). The non-lexical route entails serial processing because the graphemes are converted one by one into corresponding sound codes using the GPC rules. Reading in the DRC model can be seen as a race between these two routes meaning that both routes are simultaneously operative at an early stage. It has been argued that the MOPE reflects serial processing because it is position-dependent, i.e. the benefit from overlapping phonemes can be found only for onset phonemes but not later phonemes in a word (Forster \& Davis, 1991; Kinoshita, 2000; Schiller, 2004).

Alternatively, the so-called speech-planning account suggests that the MOPE may be due to a later process than GPC, namely the segment-to-frame association during speech planning (Kinoshita, 2000; Kinoshita \& Woollams, 2002). The segment-to-frame association process involves the retrieval of a word's phonological segments and combining them with the metrical frame of a word (e.g. number of syllables and stress pattern) to create the speech plan necessary for speech production (Levelt, Roelofs, \& Meyer, 1999). The speech-planning account explains the MOPE as a mismatch in onset phonemes in a prime-target pair causing a conflict in the speech plan that holds up the segment-to-frame association process. The serial nature of the MOPE flows naturally from this process, supported by evidence from the speech production literature showing that words are produced faster when they share 
onset segments (e.g. hut, heel, and hop) compared to they do not (e. g. hut, dance, and pole). Words sharing the rhyme did not speed up production latencies (Meyer, 1991).

Furthermore, the MOPE has been found for words that are pronounced according to regular pronunciation rules, but not for irregular (exception) words, like 'pint' (Forster \& Davis, 1991; Kinoshita \& Woollams, 2002; Mousikou et al., 2010). Forster and Davis (1991) interpreted the absence of a MOPE for irregular words within the DRC model. They stated that the retrieval of the correct pronunciation of irregular words requires activation of the lexical route, and to avoid incorrect pronunciation the non-lexical route is ignored. It is generally assumed that the MOPE reflects only the non-lexical processes (Coltheart et al., 2001; Mousikou et al., 2010). However, the presence of a regularity effect (i.e. regular words are read aloud faster than irregular words) during a conditional naming task (i.e. read aloud the words but not the non-words) suggests that both routes are active simultaneously because the slower response latencies for irregular words are explained by competing pronunciations retrieved from both routes (Kinoshita \& Woollams, 2002).

Actually, all versions of the DRC model do assume that both lexical and non-lexical routes are simultaneously active (Coltheart et al., 2001; Mousikou et al., 2010). This assumption is supported by previous findings. For example, Frost (1995) found that Hebrew word naming latencies become gradually slower with additional missing vowels supporting the idea that the non-lexical route is active, but at the same time he demonstrated frequency effects referring to activation of the lexical route. Furthermore, Schiller (2008) found a MOPE in picture naming, necessarily involving the lexical route. However, why has a MOPE never been reported for irregular words?

DRC 1.2 (Mousikou et al., 2010) suggests there might be a conflict between correct irregular pronunciations activated by the lexical route and incorrect regular pronunciations computed by the non-lexical route, slowing down overall response latencies for reading aloud irregular words. During the time needed to resolve this conflict, the processes that give rise to the MOPE are resolved as well and therefore not reflected in reaction times. In contrast, the speech-planning account (Kinoshita, 2000; Kinoshita \& Woollams, 2002) explains the absence of a MOPE for irregular words by suggesting that not only the MOPE but also the regularity effect takes place during the segment-to-frame-association of speech planning. Evidence for this comes from silent reading tasks that do not show a regularity effect, in contrast to reading aloud research, possibly because no speech planning is involved (Berent, 1997; Coltheart, Patterson, \& Leahy, 1994). The slowdown that is caused by the irregular pronunciations eliminates the MOPE for irregular words (Kinoshita \& Woollams, 2002).

The goal of the present study is to investigate how well the DRC model and the speech-planning account explain the MOPE. To be more specific, this study investigates the time course and locus of the MOPE in the process of preparing the pronunciation of a written letter string. Employing Persian as the target language in this study may be a more valid and stronger contrast of phonological transparency than the use of regular and irregular words in the English language. The omission of vowels ${ }^{1}$ in the Persian script forms many phonologically opaque words (e.g. صلح/solh/; 'peace') requiring lexical knowledge to be read aloud correctly since

\footnotetext{
${ }^{1}$ Persian is an Iranian language within the Indo-Iranian branch of Indo-European languages. The Persian script was 'Pahlavi' before it was changed to a modified version of Arabic script around 644 AD. Contemporary Persian has an alphabetic script written from right-to-left. It consists of 31 consonants and 6 vowels: three long vowels $(/ \mathrm{i} /, / \mathrm{u} /$, and $/ \mathrm{a} /)$ represented by a letter and three short vowels $(/ æ /, / \mathrm{e} /$, and $/$ $\mathrm{o} /$ ) that can be represented by a diacritic but are gradually omitted after the second grade at school. Thus, skilled Persian readers are accustomed to reading script without diacritics.
}

yields the nonwords /sælh/ or / selh/ when incorrect short vowels are inserted (Baluch \& Besner, 1991). Using an English example, the consonant string hnch could be hanch, hench, hinch, hunch, but only hunch is an existing word, requiring activation of the lexical route in the DRC model. Thus, Persian words can be compared to irregular words in western alphabetical languages, in the sense that they both need activation of the lexical route.

In addition, Persian has some inconsistent phoneme-to-grapheme correspondences (polygraphy, i.e. phonemes that correspond to multiple graphemes) which creates difficulty for spelling but not reading. One example is the phoneme $|z|$, which may

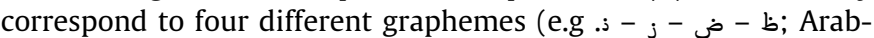
Moghaddam \& Sénéchal, 2001; Rahbari, Sénéchal, \& Arab-Moghaddam, 2007). In the current study, we took advantage of the polygraphy in Persian. To investigate a phonological MOPE we created two conditions. In the first condition, there was phonological but not orthographic onset overlap (e.g. kernel [kernəl] - CARPET [karpot]) between prime and target. In the second condition, prime and target pairs were unrelated in onset (e.g. powder - CARPET). Persian does not have capitals to avoid visual overlap between the prime and target in the overlap condition, but a phonological MOPE avoids the overlap of orthography and thus also possible visual overlapping effects (i.e., the use of different graphemes with the same phoneme سمال/s b:l /; 'year' - ملح /solh/; 'peace').

This study investigates whether native Persians read aloud transparent words (i.e. words containing long vowels which are marked in the spelling), but not opaque words (i.e. words containing short vowels not being marked), faster when preceded by phonologically congruent, onset-matching primes (e.g. respectively, م ص مال/sbil/; 'year' - صوت /sot/; 'voice'); صلح/sohl/; 'peace') compared to phonologically incongruent, onset-mismatching primes (e.g. respectively, تاب/tw:b/ 'swing' - صوت /sot/; 'voice'); صلح /solh/; 'peace'). Following Forster and Davis' (1991) interpretation of the DRC model, all versions of the DRC model (Coltheart et al., 2001; Mousikou et al., 2010) as well as the speech-planning account (Kinoshita, 2000; Kinoshita \& Woollams, 2002) predict a MOPE for transparent, but not for opaque Persian words. To help us disentangle the different accounts of MOPE, we also recorded the electroencephalogram (EEG), which might give us further insight into the underlying processes suggested by the different accounts. Recording EEG during overt single word production tasks has recently yielded very successful results for stimulus-locked studies (e.g. Costa, Strijkers, Martin, \& Thierry, 2009; Koester \& Schiller, 2008; Strijkers, Costa, \& Thierry, 2010; for a recent review of the literature see Ganushchak, Christoffels, \& Schiller, 2011), demonstrating the feasibility of the method in combination with speech production research.

Forester and Davis' interpretation of the DRC (i.e. that lexical and non-lexical route are not activated in parallel) during irregular word reading would predict a difference between the phonologically congruent and incongruent conditions early in the ERP signal for the transparent words, since they require GPC. According to a meta-analysis of reading GPC takes place approximately between 150 and $330 \mathrm{~ms}$ after target presentation (Indefrey, 2011; Indefrey \& Levelt, 2004). ${ }^{2}$ In contrast, the ERP effect should be absent for the opaque words because those are read aloud through the lexical route, which is thought not to contribute to the MOPE. However,

\footnotetext{
2 The time windows for GPC and speech-planning are based on a meta-analysis of 82 word production studies of which 25 are word reading studies. All word reading studies used Positron Emission Tomography (PET), except two which used functional Magnetic Resonance Imaging (fMRI; Indefrey \& Levelt, 2004). Indefrey (2011) confirms the previously found time windows for word production with a metaanalysis of 20 ERP studies. The preparation of the speech plan includes syllabification and phonetic encoding until the articulation of the first phoneme. This 330-600 ms time window is calculated by means of a subtraction method (for details see Indefrey \& Levelt, 2004; Indefrey, 2011)
} 
according to the DRC model perspective, we may observe a reflection of the MOPE between 150 and $330 \mathrm{~ms}$ in the ERP signal for both transparent and opaque words, because the DRC model assumes the simultaneous activation of both routes for all word reading (Coltheart et al., 2001; Mousikou et al., 2010). Based on the speech-planning account, we may predict that a MOPE is reflected later in the ERP signal, namely during the preparation of the speech plan (Kinoshita, 2000; Kinoshita \& Woollams, 2002). The metaanalysis associated speech-planning with the $330-600 \mathrm{~ms}$ time window (Indefrey, 2011; Indefrey \& Levelt, 2004). ${ }^{2}$ Thus, electrophysiological recordings (EEG) may provide a remedy to differentiate between the accounts.

\section{Method}

\subsection{Participants}

Twenty-four native Persian speakers (thirteen female) took part in the experiment in exchange for a small financial reward. The mean age of the participants was 29 years $(S D=5.75)$. All participants signed an informed consent form, had normal or correctedto-normal vision, and no history of neurological impairments or language disorders. Due to technical failure, three participants were excluded from the analysis.

\subsection{Materials}

In Persian, there are phonemes that correspond to multiple graphemes (i.e. polygraphy). The polygraphy in Persian was employed in the onset phoneme since Persian does not have small and capital letters used in western alphabetic languages to avoid visual overlap between prime and target. The following phonemes with corresponding graphemes were used (i.e. $|z|$ as $\left.\left.\langle j\rangle-<_{j}\right\rangle-<_{j}\right\rangle-$

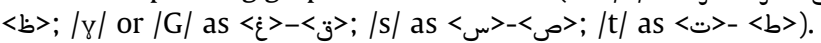

Thirty-two transparent target words were selected and combined with a phoneme-match $(\mathrm{O}-\mathrm{P}+$; onset matching in phonology but not orthography) and a phoneme-mismatch prime (O-P-; unrelated onset letter). Primes were also transparent. Thirty-two opaque target words were matched to the same prime words. An overview of the stimuli can be found in the Appendix.

All stimuli were nouns (with an exception of ten adjectives) with an average letter length of $4.0(0.9)$ for the transparent target words, $3.8(0.7)$ for the opaque target words, and $3.8(0.8)$ for the prime words.

To our knowledge, there is no lexical database available for Persian. Therefore, we carried out a survey with seven native Persian speakers to obtain a measure of familiarity for each word. Participants judged each word on a scale from 1 ("I have never heard of this word") to 7 ("I know exactly what this word means"). The average score was $6.9(0.2)$ for the transparent target words, 7.0 (0.1) for the opaque target words, and $6.8(0.5)$ for the prime words.

Moreover, 128 filler words were added, half of which were transparent and the other half opaque. The onset graphemes were $\langle\mathrm{b}\rangle,\langle\mathrm{m}\rangle,\langle\mathrm{d}\rangle,\langle\mathrm{s}\rangle$, and $\langle\mathrm{sh}\rangle$. The targets were combined with a matching $(\mathrm{O}+\mathrm{P}+$; onset matching in phonology and orthography) and a mismatching prime ( $\mathrm{O}-\mathrm{P}-$; unrelated onset letter). The average length and frequency of the fillers was matched to that of the experimental ones.

\subsection{Procedure and design}

Participants were seated individually in front of a computer screen in a dimly lit, soundproof room. They were instructed to read aloud target words presented on the screen as fast and as accurately as possible. The visually masked prime words preceding the targets were not mentioned. A voice-key measured the onset of the vocal responses. In addition, EEG was recorded when the participants carried out the experiment.

Instructions were given written in the language of the experiment. Five additional prime-target combinations preceded the experiment to familiarize participants with the task. The experiment consisted of 256 trials, divided into four blocks of 64 trials with breaks in between. Each target word was presented twice (128 target words $*$ two priming conditions). Each prime word was also repeated ( 128 prime words $*$ two target words). The stimuli were presented in pseudo-random order. In the first two blocks, all transparent or all opaque target words were presented. In the last two blocks, the other group of target words was presented (i. e. factor: Order). Within the first block, the target words were presented in one of the two priming conditions. In the second block, these primes were presented in the other condition. The same holds between blocks three and four. Blocks were counterbalanced across participants.

All stimuli were presented in black letters on a white background and centered on the screen. Each trial started with a fixation point presented between 500 and $800 \mathrm{~ms}$, followed by a 500 ms forward mask consisting of a row seven hashes ('\#'). Then, a prime word was presented for $48 \mathrm{~ms}$ matching the length of the target word by adding percent signs (\%) before and after the prime to avoid flickering on the screen, followed by a $17 \mathrm{~ms}$ presentation of a backward mask that was identical to the forward mask. Finally, the target word was presented for a maximum of $2000 \mathrm{~ms}$ or disappeared after a response was given, followed by a blank screen for $1000 \mathrm{~ms}$ before the start of the next trial.

\subsection{Electrophysiological recording and analysis}

The electroencephalogram (EEG) was recorded using $32 \mathrm{Ag} /$ $\mathrm{AgCl}$ electrodes on the standard scalp sites of the extended international 10/20 system. Six electrodes of the flat type were used to measure the eye blinks (above and underneath the left eye), horizontal eye movements (at the external canthi of both eyes), and a baseline (one at each mastoid) for off-line re-referencing. The EEG signal was sampled at $512 \mathrm{~Hz}$, and off-line band-pass filtered from 0.01 to $40 \mathrm{~Hz}$. Epochs from -300 to $+600 \mathrm{~ms}$ were computed, including a -300 to $-100 \mathrm{~ms}$ pre-stimulus baseline. For the correction of EOG artifacts, the Gratton, Coles, and Donchin (1983) algorithm was applied. For non-ocular artifacts, trials with amplitudes below $-200 \mu \mathrm{V}$, above $+200 \mu \mathrm{V}$, or trials that made a $100 \mu \mathrm{V}$ or larger voltage step within $200 \mathrm{~ms}$ were removed from the analysis. The ERP grand averages were time-locked to the onset of the target word and calculated across all participants for both Phonology (phoneme-match vs. mismatch condition) and Transparency (transparent vs. opaque).

\section{Results}

\subsection{Behavioral data}

Incorrect responses ( $0.6 \%$ of the data), as well as voice-key errors ( $2.6 \%$ of the data) and outliers (i.e. naming latencies faster than $200 \mathrm{~ms}$ and slower than $1000 \mathrm{~ms} ; 0.9 \%$ of the data) were removed from the analysis, but were too few to run a meaningful error analysis.

A mixed-effects model analysis was carried out with the factor Phonology (phoneme-match; $\mathrm{O}-\mathrm{P}+$ vs. phoneme-mismatch; $\mathrm{O}-\mathrm{P}-$ ) and Transparency (Transparent vs. Opaque) as crossed fixed factors. Multiple random factors, participants and prime items, could be included concurrently in the present analysis (Brysbaert, 
2007; Quené \& Van den Bergh, 2008). The dependent variable, RTs, was rendered to a logarithmic transformation to remove the intrinsic positive skew and the non-normality of the distribution (Keene, 1995; Limpert Stahel, \& Abt, 2001; Quené \& Van den Bergh, 2008). The denominator degrees of freedom in a mixed-effects model analysis are based on the Satterthwaite method (Satterthwaite, 1946; see also Janssen, 2012).

There was a main effect of both Phonology $(F(1,2475)=7.98$, $p<.01)$, with shorter speech onset latencies for the phonemematch condition ( $634 \mathrm{~ms}, \mathrm{SE}=20.39$ ) than the phoneme-mismatch condition $(640 \mathrm{~ms}, \mathrm{SE}=20.39)$. There was also a main effect of Transparency $(F(1,19)=5.43, p<.05)$, with shorter speech onset latencies for the transparent words $(627 \mathrm{~ms}, \mathrm{SE}=21.17)$ than the opaque words $(647 \mathrm{~ms}, \mathrm{SE}=21.17)$. These main effects were qualified by an interaction between the two $(F(1,2475)=3.87, p<.05)$. The results were not influenced by Order (Order, Order by Phonology, and Order by Phonology by Transparency $(F<1)$ and Order by Transparency $(F(1,19)=1.77, n s))$.

To further investigate the interaction, two separate analyses were run, one for each Transparency type. The transparent words reveal a main effect of Phonology $(F(1,1221)=11.11, p<.005)$, i. e. speech onset latencies in the phoneme-match condition (e.g. SD:l/; 'year' - موت سوال/sot/; 'voice'; 622 ms, SE = 20.03) were 12 ms shorter than in the phoneme-mismatch condition (e.g. تماب |to:b/ 'swing' - صوت /sot/; 'voice'; 634 ms, SE = 20.03). The opaque words did not reveal a main effect of Phonology $(F<1)$, i. e. there was no difference in speech onset latencies between the phoneme-match (e.g. سمال/sb:l/; 'year' - ملح /solh/; 'peace'; $647 \mathrm{~ms}, \mathrm{SE}=20.87$ ) and the phoneme mismatch condition (e.g. /to:b/ 'swing' - صلح/solh/; 'peace'; 647 ms, SE = 20.87).

\subsection{ERP data}

The onset and offset of two time windows (80-160 and 300$480 \mathrm{~ms}$ ) were determined by ANOVAs for averaged $20 \mathrm{~ms}$ time windows from 0 to $600 \mathrm{~ms}$ after target onset. For three consecutive $20 \mathrm{~ms}$ time windows at least two had to reveal significant effects. Time windows were empirically chosen from the first to the last significant time window within three consecutive ones. The mean amplitudes for these time windows were submitted to an ANOVA with Phonology (phoneme-match vs. phoneme-mismatch), Transparency (transparent vs. opaque), and Localization (anterior: AF3, AF4, F7, F3, Fz, F4, F8, FC5, FC1, FC2, FC6, vs. posterior: PO3, PO4, P7, P3, Pz, P4, P8, CP5, CP1, CP2, CP61) as independent factors. An additional ANOVA was run with Lateralization (left: AF3, F3, F7, FC1, FC5, C3, T7, CP1, CP5, P3, P7, PO3, vs. right: AF4, F4, F8, FC2, FC6, C4, T8, CP2, CP6, P4, P8, PO4) instead of Localization. ERP waveforms of the phonological priming effect for the transparent and opaque words can be found in Fig. 1.

\subsubsection{0-160 ms time window}

The analysis with Localization revealed a main effect of Phonology $(F(1,20)=4.77, M S e=72.34, p<.05)$ but not of Transparency $(F$ $(1,20)=1.35, M S e=48.67, n s)$. None of the interactions reached
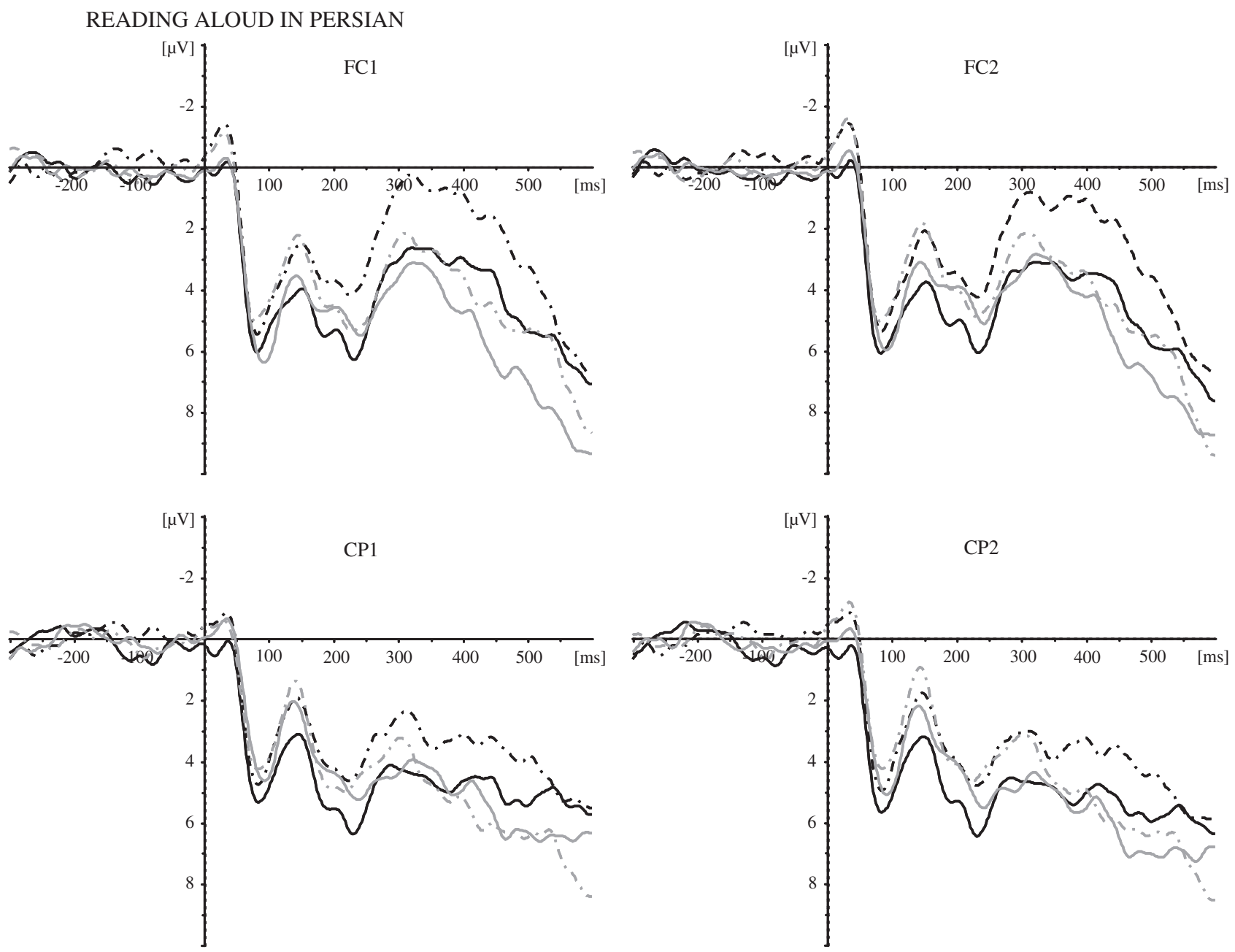

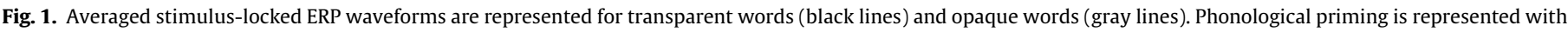
phoneme-match ( $\mathrm{O}-\mathrm{P}+$; solid lines) vs. phoneme-mismatch ( $\mathrm{O}-\mathrm{P}-$; dashed lines) conditions. (A $20 \mathrm{~Hz}$ filter was applied for the clarity of the waveforms.). 
significance (Localization by Phonology: $F(1,20)=1.27, M S e=6.65$, $n s$; Localization by Phonology by Transparency: $F(1,20)=2.15$, $M S e=7.36$, ns; all other $F s<1)$. Across the entire scalp, the phoneme-mismatch condition $(2.45 \mu \mathrm{V} ; \mathrm{SD}=0.42)$ revealed more negative mean amplitudes than the phoneme-match condition (3.32 $\mu \mathrm{V} ; \mathrm{SD}=0.56)$.

The analysis with Lateralization revealed the same results as for Localization. More specifically, a main effect of Phonology $(F(1,20)$ $=4.63, M S e=76.68, p<.05)$ but not of Transparency $(F(1,20)$ $=1.42, M S e=48.26, n s)$ was found. None of the interactions reached significance (all $F s<1$ ).

\subsubsection{0-480 ms time window}

The analysis with Localization revealed a marginally significant main effect of Phonology $(F(1,20)=3.80$, MSe $=128.75, p<.07)$ and the main effect of Transparency was significant $(F(1,20)=5.85$, $M S e=151.47, p<.05)$. The latter effect was qualified by an interaction with Localization $(F(1,20)=10.76, M S e=8.98, p<.005)$. No other interactions reached significance (Localization by Phonology: $F(1,20)=2.48, M S e=21.06$, $n s ;$ Phonology by Transparency: $F$ $(1,20)=2.65, M S e=90.90, n s$; Localization by Phonology by Transparency: $F<1$ ).

To further investigate the significant interaction between Localization and Transparency, two separate follow-up ANOVAs were run per brain region. The anterior region revealed a main effect of Transparency $(F(1,20)=8.83, M S e=88.79, p<.01)$. Transparent words $(2.77 \mu \mathrm{V} ; \mathrm{SD}=1.60)$ yielded more negative mean amplitudes compared to the opaque words $(4.61 \mu \mathrm{V}$; $\mathrm{SD}=1.36)$. Visual inspection of Fig. 1 suggests an interaction between Transparency and Phonology, however, statistical analyses showed no significant effect $(F<1)$.

The posterior region did not reveal a main effect of Transparency $(F(1,20)=2.77, M S e=71.66, n s)$. However, there was an interaction between the two $(F(1,20)=5.34, M S e=33.66, p<.05)$. Although the tree-way-interaction between Localization, Phonology, and Transparency in the main ANOVA was not significant, we looked at effects of Phonology for each Transparency type. The reason for this is that following our hypothesis and based on the results of our behavioral data we expected a difference in main effects of Phonology for Transparency, and that is why we felt licensed to analyze the effects of Phonology for each Transparency type separately. Transparent words revealed a main effect of Phonology $(F(1,20)=5.71, M S e=50.21, p<.05)$, i.e. the phonememismatch condition $(2.82 \mu \mathrm{V} ; \mathrm{SD}=1.29)$ yielded more negative mean amplitudes than the phoneme-match condition $(4.40 \mu \mathrm{V}$; $\mathrm{SD}=1.39$ ). Opaque words, in contrast, did not reveal a main effect of Phonology $(F<1)$, i.e. the phoneme-mismatch $(4.63 \mu \mathrm{V}$; $\mathrm{SD}=1.02)$ and the phoneme-match condition $(4.44 \mu \mathrm{V} ; \mathrm{SD}=$ 1.17) did not differ in mean amplitudes.

The analysis with Lateralization revealed a marginally significant main effect of Phonology $(F(1,20)=3.92, \quad M S e=137.57$, $p<.07)$ and the main effect of Transparency was significant $(F$ $(1,20)=5.82, M S e=159.81, p<.05)$. None of the interactions were significant (Localization by Transparency: $F(1,20)=2.89, M S e=$ 3.86, ns; Phonology by Transparency: $F(1,20)=2.53, M S e=95.98$, $n s$; all other $F s<1$ ).

\section{Discussion}

The current study investigated the presence of a MOPE for transparent Persian words (i.e. words with marked vowels) versus opaque Persian words (i.e. words with vowels not marked) and how different models of reading aloud account for the obtained effects. As predicted, for transparent Persian words, participants read targets faster when they were preceded by phonologically matching (e.g.J سمال/Sb:l/; 'year' - صوت /sot/; 'voice') than phonologically mismatching primes (e.g. تاب/to:b/ 'swing' صوت /sot/; 'voice'). For opaque Persian target words, however, we found no priming effect. The presence of a MOPE for transparent Persian words is similar to previous findings for western alphabetic languages. Namely, faster reading of target words when a preceding prime shared the onset phonology with the target (e.g. kachel - CONGRES) compared to mismatching onset phonology (e. g. grendel - CONGRES; Schiller, 2007; see also Carreiras et al., 2005; Carreiras et al., 2009; Grainger \& Ferrand, 1996; Mousikou et al., 2010; Timmer \& Schiller, submitted). The presence of a MOPE for transparent, but not opaque, Persian words is also in agreement with the presence of a MOPE for regular as opposed to irregular English words (Forster \& Davis, 1991; Kinoshita \& Woollams, 2002; Mousikou et al., 2010).

Forster and Davis (1991) suggested that a MOPE takes place in the non-lexical route of the DRC model. During reading aloud of irregular words (e.g. pint), the correct pronunciation (i.e. /paint/) is activated via the lexical route, while the incorrect pronunciation (i.e. /pint/) of the non-lexical route is ignored. Since the MOPE is supposed to originate in the non-lexical route, no MOPE is observed for irregular words. However, according to the DRC model (Coltheart et al., 2001; Mousikou et al., 2010), both routes are active concurrently, and the absence of a MOPE in the RTs for irregular words in English (e.g. pint) may be caused by a conflict between the incorrect pronunciation (i.e. /pint/) and the correct pronunciation (i.e. /paint/), slowing down processing and dissolving potential earlier effects, like the MOPE (Coltheart et al., 2001; Mousikou et al., 2010).

Similarly to irregular English words, opaque Persian words may have been slowed down. Persian is different from western alphabetic languages due to the omission of three of the six vowels in the script yielding phonologically opaque words consisting only of consonants. To insert the appropriate vowel, all possible options activated through the non-lexical route have to be checked with the lexical entry or entries using the lexical route. The multiple options for vowel insertion may slow down naming. The idea that opaque words, without printed vowels, are read slower than transparent words, with printed vowels, is well supported by behavioral studies on Persian (Baluch, 1990; Baluch, 1993), Arabic (Abu-Rabia, 1997), and Hebrew (Frost, 1995). The current study also reveals slower speech onset latencies for opaque than transparent words. This slow-down may have eliminated a potential MOPE in the RTs for opaque Persian words.

Taken together, our behavioral results are in line with previous research in alphabetic languages. However, the Persian behavioral results cannot differentiate between the different accounts on the locus of the MOPE; i.e., an early locus (GPC in the non-lexical route of DRC; Coltheart et al., 2001; Mousikou et al., 2010) versus a late locus (segment-to-frame association in speech planning; Kinoshita, 2000). The EEG recordings help here because they track the online neural activation, prior to the behavioral response. Contrary to the behavioral results, the ERP data showed that in the $80-160 \mathrm{~ms}$ time window there were more negative amplitudes for the phoneme-mismatch condition than for the phoneme-match condition for both transparent and opaque target words. This phonological onset effect was widely distributed across the entire scalp. This early time window corresponds at the lower limit with the time of phonological code retrieval in visual word recognition between 150 and $330 \mathrm{~ms}$ (Indefrey, 2011; Indefrey \& Levelt, 2004) and is in line with an early locus of the MOPE as suggested by the DRC model (Coltheart et al., 2001; Mousikou et al., 2010). Two recent masked priming studies investigating silent reading demonstrated a similar phonological priming effect, with less negativity for the congruent than incongruent condition, within the same time window for sub-phonemic features (80-180 ms; Ashby, Sanders, \& 
Kingston, 2009) and for phonological syllables (100-120 ms; Ashby, 2010). These studies, and the present, add to the evidence of automatic sub-lexical phonological activation from GPC in silent reading and reading aloud.

The later time window, 300-480 ms, suggested a MOPE over the posterior brain region for transparent Persian words, but not for opaque Persian words. This is in line with our behavioral results and the hypothesis that co-activation of multiple options for pronunciation slows down processing and eliminates the MOPE at the endpoint of processing (i.e. reflected in the later ERP time window and the RTs). In the case of picture naming, there is no slowdown due to potential conflicting activations, and therefore the MOPE is present in the behavioral data for picture naming (Schiller, 2008) but not opaque Persian word reading (present study) and irregular word reading (Forster \& Davis, 1991; Kinoshita \& Woollams, 2002; Mousikou et al., 2010).

Furthermore, during the same time window, we showed more negative amplitudes for transparent compared to opaque Persian words over the anterior brain region. It is possible that there are fewer transparent than opaque words in the Persian language, which would agree with more negative amplitudes for low-frequency and low-predictability words compared to high-frequency and high-predictability words (Dambacher, Kliegl, Hofmann, \& Jacobs, 2006; Rugg, 1990).
To summarize, the present behavioral results showed a MOPE for transparent Persian words, but not for opaque Persian words. However, an early ERP time window, i.e. $80-160 \mathrm{~ms}$, showed an identical MOPE for both transparent and opaque Persian words. This effect continued into a later ERP time window, i.e. 300$480 \mathrm{~ms}$, but only for transparent and not opaque words. This suggests that not only the lexical route (i.e. absence of a MOPE in RTs), but also the non-lexical route was active (i.e. early ERP effect) during reading aloud. This is in accordance with previous behavioral studies (Frost, 1995; Schiller, 2008) and the DRC model (Coltheart et al., 2001; Mousikou et al., 2010). Furthermore, we suggest that the present data support the early locus of the MOPE. It would be interesting to investigate whether a MOPE may be revealed in the ERP signal for irregular English words as well.

\section{Acknowledgment}

The author would like to thank Ilse Ceusters for recruiting participants and running the experiment as well as Lourens Waldorp and Dirk Janssen for their input on the mathematical background regarding mixed-effects model analysis.

\section{Appendix}




\begin{tabular}{|c|c|c|c|c|c|c|c|}
\hline $\begin{array}{l}\text { Transparent } \\
\text { target word }\end{array}$ & $\begin{array}{l}\text { Phonological } \\
\text { transcription } \\
\text { (IPA) and English } \\
\text { translation }\end{array}$ & $\begin{array}{l}\text { Opaque } \\
\text { target } \\
\text { word }\end{array}$ & $\begin{array}{l}\text { Phonological } \\
\text { transcription } \\
\text { (IPA) and English } \\
\text { translation }\end{array}$ & $\begin{array}{l}\text { Phonological- } \\
\text { matching } \\
\text { prime }\end{array}$ & $\begin{array}{l}\text { Phonological } \\
\text { transcription } \\
\text { (IPA) and English } \\
\text { translation }\end{array}$ & $\begin{array}{l}\text { Phonological- } \\
\text { mismatching } \\
\text { prime }\end{array}$ & $\begin{array}{l}\text { Phonological } \\
\text { Transcription } \\
\text { (IPA) and English } \\
\text { Translation }\end{array}$ \\
\hline غول & /yu:l/ ('giant') & غسل & /yosl / ('wash') & قاب & /G o:b/ ('frame') & 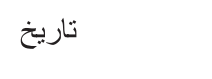 & $\begin{array}{l}\text { /t p:ri:x/ } \\
\text { ('history') }\end{array}$ \\
\hline غوره & $\begin{array}{l}\text { /yu: re / ('sour } \\
\text { grapes') }\end{array}$ & غرفه & /yorfe/ ('booth') & قاطع & $\begin{array}{l}\text { /G p:te ?/ } \\
\text { ('desicive') }\end{array}$ & ثانى & $\begin{array}{l}\text { /s o:ni:/ } \\
\text { ('second') }\end{array}$ \\
\hline قوم & /Gom / ('people') & قفل & /Gofl/ ('lock') & غاز & / у p:z/ ('goose') & صاف & /s o:f/ ('flat') \\
\hline 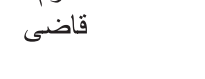 & /Gn:zi:/ ('judge') & قهوه & $\begin{array}{l}\text { /Gæhve / } \\
\text { ('coffee') }\end{array}$ & غوطه & /yu:te/ ('soak') & تابه & $\begin{array}{l}\text { /t } \mathrm{n}: \text { be/ ('frying } \\
\text { pan') }\end{array}$ \\
\hline & /su:p/ ('soup’) & سكه & / seke/ ('coin') & صاف & /s p:f/ ('flat') & 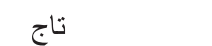 & /t o:j/ ('crown') \\
\hline ساقه & /sb:Ge/ ('stem') & سركه & $\begin{array}{l}\text { /serke / } \\
\text { ('vinegar') }\end{array}$ & صوفى & $\begin{array}{l}\text { /su:fi:/ ('sufi/ } \\
\text { mystic') }\end{array}$ & زيبا & $\begin{array}{l}\text { /zi:b o:/ } \\
\text { ('beautiful') }\end{array}$ \\
\hline صورى & $\begin{array}{l}\text { /su:ri: / } \\
\text { ('superficial') }\end{array}$ & صحبت & $\begin{array}{l}\text { / sohbæt/ } \\
\text { ('speech') }\end{array}$ & 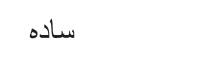 & /s o:de/ ('simple’) & طاقت & $\begin{array}{l}\text { /t o:Gæt/ } \\
\text { ('endurance') }\end{array}$ \\
\hline صابون & /sb:bu:n / ('soap') & صحنه & /sæhne/ ('scene') & سوسيس & $\begin{array}{l}\text { /sosi:s/ } \\
\text { ('sausage') }\end{array}$ & طو لانى & /tu:l p:ni:/ ('long') \\
\hline توبٌ & /tu:p / ('ball') & تخت & /tæxt / ('bed') & طاس طاس & /t p:s/ ('bald') & 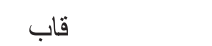 & /G p:b/ ('frame') \\
\hline تيره & /ti:re/ ('dark') & تفنى & /tofæng/ ('gun') & طاووس & $\begin{array}{l}\text { /t p:vu:s/ } \\
\text { ('peakcock') }\end{array}$ & ساده & /s n:de/ ('simple') \\
\hline ت تابوت & $\begin{array}{l}\text { /to:bu:t / } \\
\text { ('coffin') }\end{array}$ & ترجمه & $\begin{array}{l}\text { /tærdzome/ } \\
\text { ('translation') }\end{array}$ & طوفان & $\begin{array}{l}\text { /tu:f p:n/ } \\
\text { ('storm') }\end{array}$ & سوسيس & $\begin{array}{l}\text { /sosi:s/ } \\
\text { ('sausage') }\end{array}$ \\
\hline طوطى & /tu:ti: / ('parrot') & طنز & $\begin{array}{l}\text { /tænz / } \\
\text { ('comedy') }\end{array}$ & تاب & /t p:b/ ('swing') & 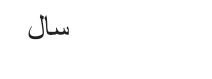 & /s o:l/ ('year') \\
\hline طول & /tu:1 / ('length’) & طفل & /tefl/ ('child') & 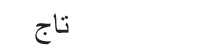 & /t p: d / ('crown') & غاز & / у р:z/ ('goose') \\
\hline طاق & /to:G/ ('arch') & طبل & /tæbl/ ('drum') & توت & /tu:t/ ('berry') & 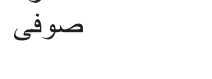 & $\begin{array}{l}\text { /su:fi:/ ('sufi/ } \\
\text { mystic') }\end{array}$ \\
\hline ذاتى & $\begin{array}{l}\text { /zorti:/ ('inherent. } \\
\text { natural') }\end{array}$ & ذخيره & $\begin{array}{l}\text { /zæXi:re/ } \\
\text { ('reservoir') }\end{array}$ & 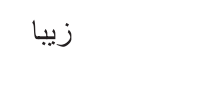 & $\begin{array}{l}\text { /zi:b o:/ } \\
\text { ('beautiful') }\end{array}$ & غوج & / y u: ts / ('ram') \\
\hline زانو & /zo:nu: / ('knee') & زنـ & /zæng/ ('bell') & 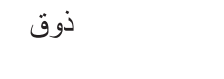 & $\begin{array}{l}\text { |zoG/ } \\
\text { ('enjoyment') }\end{array}$ & طور & $\begin{array}{l}\text { /tor/ ('manner/ } \\
\text { kind') }\end{array}$ \\
\hline غوغا & /уоур: / ('uproar') & غيبت & $\begin{array}{l}\text { /yejbæt / } \\
\text { ('absence') }\end{array}$ & قاره & $\begin{array}{l}\text { /G o:re/ } \\
\text { ('continent') }\end{array}$ & صافى & $\begin{array}{l}\text { /s o:ni:/ } \\
\text { ('strainer/filter') }\end{array}$ \\
\hline قول & /Gol / ('promise') & قله & / Gole/ ('peak') & غار & /y o:r/ ('cave') & طاس & /t o:s/ ('bald’) \\
\hline 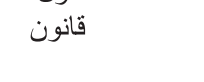 & /Go:nun / ('law') & قلم مو & $\begin{array}{l}\text { /Gælæmu: / } \\
\text { ('brush') }\end{array}$ & غوج & /yu: ts / ('ram') & زور & /zu:r/ ('force') \\
\hline سينه & $\begin{array}{l}\text { /si:ne / ('bosom/ } \\
\text { chest') }\end{array}$ & سكته & /sekte/ ('stroke') & ثانى & $\begin{array}{l}\text { /s p:ni:/ } \\
\text { ('second') }\end{array}$ & 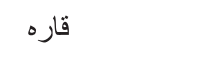 & $\begin{array}{l}\text { /G p:re/ } \\
\text { ('continent') }\end{array}$ \\
\hline سيما & /si:mo:/ ('visage') & سنبل & $\begin{array}{l}\text { /sonbol/ } \\
\text { ('hyacinth') }\end{array}$ & صافى & $\begin{array}{l}\text { /s b:fi:/ ('strainer/ } \\
\text { filter') }\end{array}$ & طاووس & $\begin{array}{l}\text { /t p:vu:s/ } \\
\text { ('peakcock') }\end{array}$ \\
\hline سايه & $\begin{array}{l}\text { /s p:je/ ('shade/ } \\
\text { shadow') }\end{array}$ & سرقت & /serGæt/ ('theft') & صيغه & $\begin{array}{l}\text { /si: ye/ } \\
\text { ('concubine') }\end{array}$ & تيز & /ti:z/ ('sharp') \\
\hline صوت & /sot/ ('voice') & صلح & /solh/ ('peace') & سال سال & /s o:1/ ('year') & تاب & /t o:b/ ('swing') \\
\hline صافكارى & $\begin{array}{l}\text { /s p:fk p:ri:/ } \\
\text { ('moothen') }\end{array}$ & صخره & /sæXre/ ('cliff') & سوغات & $\begin{array}{l}\text { /soy b:t/ } \\
\text { ('souvenir') }\end{array}$ & طوفان & $\begin{array}{l}\text { /tu:f p:n/ } \\
\text { ('storm') }\end{array}$ \\
\hline 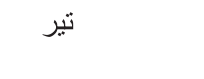 & /ti:r / ('bullet') & تلفن & $\begin{array}{l}\text { /telefon/ } \\
\text { ('telephone') }\end{array}$ & طاقت & $\begin{array}{l}\text { /t p:Gæt/ } \\
\text { ('endurance') }\end{array}$ & قاطع & $\begin{array}{l}\text { /G p:ter/ } \\
\text { ('desicive') }\end{array}$ \\
\hline 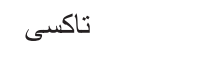 & /t o:ksi: / ('taxi') & تجربه & $\begin{array}{l}\text { /tæd3robe/ } \\
\text { ('experience') }\end{array}$ & طور & $\begin{array}{l}\text { /tor/ ('manner/ } \\
\text { kind') }\end{array}$ & ذ & $\begin{array}{l}\text { |zoG/ } \\
\text { ('enjoyment') }\end{array}$ \\
\hline ت ت تالار & /t p:l p:r/ ('salon') & تحصيل & $\begin{array}{l}\text { /tæhsi:1/ } \\
\text { ('education') }\end{array}$ & طو لانى & $\begin{array}{l}\text { /tu:l p:ni:/ } \\
\text { ('long') }\end{array}$ & سوغات & $\begin{array}{l}\text { /so y } \mathrm{o:t} / \\
\text { ('souvenir') }\end{array}$ \\
\hline 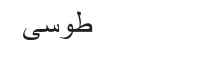 & /tu:si: / ('gray') & طلسم & /telesm/ ('curse') & تابه & $\begin{array}{l}\text { /t } \mathrm{o}: \text { be/ ('frying } \\
\text { pan') }\end{array}$ & صيغه & $\begin{array}{l}\text { /si: y e/ } \\
\text { ('concubine') }\end{array}$ \\
\hline طومار & $\begin{array}{l}\text { /tu:m o:r / } \\
\text { ('scroll') }\end{array}$ & طبيعت & $\begin{array}{l}\text { /tæbi: æt/ } \\
\text { ('nature') }\end{array}$ & تاريخ & $\begin{array}{l}\text { /t p:ri:x/ } \\
\text { ('history') }\end{array}$ & ضايع & /z o:je / ('wasted') \\
\hline طاقجه & $\begin{array}{l}\text { /t } \mathrm{p}: G \text { tSe/ } \\
\text { ('shelf') }\end{array}$ & طناب & /tæn o:b/ ('rope') & تيز & |ti:z/ ('sharp') & غوطه & / y u:te/ ('soak') \\
\hline زود - ز & /zu:d / ('early') & 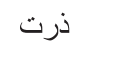 & /zoræt/ ('corn') & ضايع & $\begin{array}{l}\text { /z p:je / } \\
\text { ('wasted') }\end{array}$ & غار & / y р:r ('cave') \\
\hline 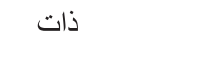 & $\begin{array}{l}\text { / } z: t / \text { ('nature/ } \\
\text { soul') }\end{array}$ & ظرف & /zærf/ ('dish') & 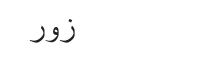 & /zu:r/ ('force') & توت & /tu:t/ ('berry') \\
\hline
\end{tabular}




\section{References}

Abu-Rabia, S. (1997). The effect of arabic vowels on the reading comprehension of second-and sixth-grade native arab children. Journal of Psycholinguistic Research, 28, 93-101.

Arab-Moghaddam, N., \& Sénéchal, M. (2001). Orthographic and phonologica processing skills in reading and spelling in Persian/English bilinguals. International Journal of Behavioral Development, 25, 140-147.

Ashby, J. (2010). Phonology is fundamental in skilled reading: Evidence from ERPs. Psychonomic Bulletin and Review, 17, 95-100.

Ashby, J., Sanders, L. D., \& Kingston, J. (2009). Skilled readers begin processing subphonemic features by $80 \mathrm{~ms}$ during visual word recognition: Evidence from ERPs. Biological Psychology, 80, 84-94.

Baluch, B. (1990). Word recognition in Persian. Baranoosh Scientific Quarterly, 1, 3-6.

Baluch, B. (1993). Lexical decisions in Persian: A test of the orthographic depth hypothesis. International Journal of Psychology, 28, 19-29.

Baluch, B., \& Besner, D. (1991). Visual word recognition: Evidence for strategic control of lexical and nonlexical routines in oral reading. Journal of Experimental Psychology: Learning, Memory and Cognition, 17, 644-652.

Berent, I. (1997). Phonological priming in the lexical decision task: Regularity effects are not necessary evidence for assembly. Journal of Experimental Psychology: Human Perception and Performance, 23, 1727-1742.

Carreiras, M., Ferrand, L., Grainger, J., \& Perea, M. (2005). Sequential effects of phonological priming in visual word recognition. Psychological Science, 16, 585-589.

Carreiras, M., Perea, M., Vergara, M., \& Pollatsek, A. (2009). The time course of orthography and phonology: ERP correlates of masked priming effects in Spanish. Psychophysiology, 46, 1113-1122.

Coltheart, M., Patterson, K., \& Leahy, J. (1994). When a ROWS is a ROSE: Phonological effects in written word comprehension. Quarterly Journal of Experimental Psychology, 47A, 917-955.

Coltheart, M., Rastle, K., Perry, C., Langdon, R., \& Ziegler, J. (2001). DRC: A dual route cascaded model of visual word recognition and reading aloud. Psychological Review, 108, 204-256.

Costa, A., Strijkers, K., Martin, C., \& Thierry, G. (2009). The time course of word retrieval revealed by event-related brain potentials during overt speech. Proceedings of the National Academy of Sciences of the USA, 106, 21442-21446.

Dambacher, M., Kliegl, R., Hofmann, M., \& Jacobs, A. M. (2006). Frequency an predictability effects on event-related potentials during reading. Brain Research, 1084, 89-103.

Dimitropoulou, M., Duñabeitia, J. A., \& Carreiras, M. (2010). Influence of prime lexicality, frequency, and pronounceability on the masked onset priming effect. The Quarterly Journal of Experimental Psychology, 63, 1813-1837.

Forster, K. I., \& Davis, C. (1991). The density constraint on form-priming in a naming task: Interference effects from a masked prime. Journal of Memory and Language, $30,1-25$.

Frost, R. (1995). Phonological computation and missing vowels: Mapping lexical involvement in reading. Journal of Experimental Psychology: Learning, Memory, and Cognition, 2, 398-408.

Ganushchak, L. Y., Christoffels, I. K., \& Schiller, N. O. (2011). The use of electroencephalography in language production research: A review. Frontiers in Psychology, 2, 208.

Grainger, J., \& Ferrand, L. (1996). Masked orthographic and phonological priming in visual word recognition and naming: Cross-task comparisons. Journal of Memory and Language, 35, 623-647.

Gratton, G., Coles, M. G. H., \& Donchin, E. (1983). A new method for off-line removal of ocular artifact. Electroencephalography and Clinical Neurophysiology, 55, 468-484.
Indefrey, P. (2011). The spatial and temporal signatures of word production components: A critical update. Frontiers in Psychology, 2, 1-16.

Indefrey, P., \& Levelt, W. J. M. (2004). The spatial and temporal signatures of word production components. Cognition, 92, 101-144.

Janssen, D. P. (2012). Twice random, once mixed: applying mixed models to simultaneously analyze random effects of language and participants. Behavior Research Methods, 44, 232-247.

Keene, O. N. (1995). The log transformation is special. Statistics in Medicine, 14, 811-819.

Kinoshita, S. (2000). The left-to-right-nature of the masked onset priming effect in naming. Psychological Bulletin and Review, 7, 133-141.

Kinoshita, S. (2003). The nature of masked onset priming effects in naming. In S Kinoshita \& S. L. Lupker (Eds.), Masked priming: The state of the art (pp. 223-238). New York: Psychology Press.

Kinoshita, S., \& Woollams, A. (2002). The masked onset priming effect in naming: Computation of phonology or speech-planning. Memory and Cognition, 30, 237-245.

Koester, D., \& Schiller, N. O. (2008). Morphological priming in overt language production: Electrophysiological evidence from Dutch. Neurolmage, 42, $1622-1630$.

Levelt, W. J. M., Roelofs, A., \& Meyer, A. S. (1999). A theory of lexical access in speech production. Behavioral and Brain Sciences, 22, 1-38.

Limpert, E., Stahel, W. A., \& Abbt, M. (2001). Lognormal distributions across the science: keys and clues. Bioscience, 51, 341-352.

Malouf, T., \& Kinoshita, S. (2007). Masked onset priming effect for high-frequency words: Further support for the speech-planning account. Quarterly Journal of Experimental Psychology, 80, 1155-1167.

Meyer, A. S. (1991). The time course of phonological encoding in language production: Phonological encoding inside a syllable. Journal of Memory and Language, 30, 69-89.

Mousikou, P., Coltheart, M., \& Saunders, S. (2010). Computational modeling of the masked onset priming effect in reading aloud. European Journal of Cognitive Psychology, 22, 725-763.

Quené, H., \& Van den Bergh, H. (2008). Examples of mixed-effects modeling with crossed random effects and with binomial data. Journal of Memory and Language, 59, 413-425.

Rahbari, N., Sénéchal, M., \& Arab-Moghaddam, N. (2007). The role of orthographic and phonological processing skills in the reading and spelling of monolingual Persian children. Reading and Writing, 20, 511-533.

Rastle, K., \& Brysbaert, M. (2006). Masked phonological priming effects in English: Are they real? Do they matter? Cognitive Psychology, 53, 97-145.

Rugg, M. D. (1990). Event-related brain potentials dissociate repetition effects of high- and low-frequency words. Memory and Cognition, 18, 367-379.

Satterthwaite, F. E. (1946). An approximate distribution of estimates of variance components. Biometrics Bulletin, 2, 110-114.

Schiller, N. O. (2004). The onset effect in word naming. Journal of Memory and Language, 50, 477-490.

Schiller, N. O. (2007). Phonology and orthography in reading aloud. Psychonomic Bulletin and Review, 3, 460-465.

Schiller, N. O. (2008). The masked onset priming effect in picture naming. Cognition, $106,92-956$

Seidenberg, M. S., \& McClelland, J. L. (1989). A distributed, developmental model of word recognition and naming. Psychological Review, 96, 523-568.

Strijkers, K., Costa, A., \& Thierry, G. (2010). Tracking lexical access in speech production: electrophysiological correlates of word frequency and cognate effects. Cerebral Cortex, 20, 913-928.

Timmer, K. \& Schiller, N. O. (submitted for publication). The role of orthography and phonology in English: An ERP study on first and second language reading aloud. 